DOI: $10.2478 / \mathrm{v} 10014-011-0006-8$

COBISS Code 1.01

Agrovoc descriptors: prunus, leaves ,pcr, inhibition, rna, extraction, diagnosis, potyviruses, plum pox potyvirus, prunus persica,peaches, prunus armeniaca, apricots, prunus domestica, prunus insititia,plums

Agris category code: h20, f30

\title{
Total RNA extraction method and Prunus species influence the detection of Plum pox potyvirus by real-time RT-PCR
}

\author{
Irena MAVRIČ PLEŠKO ${ }^{1 *}$, Mojca VIRŠČEK MARN², Nataša TOPLAK ${ }^{3}$
}

Received: December 11, 2010; accepted: May 3, 2011.

Delo je prispelo: 11. decembra 2010; sprejeto: 3. maja, 2011.

\begin{abstract}
Successful total RNA (totRNA) extraction is a prerequisite for a successful real-time PCR. In the present work we compared one manual and one automated totRNA extraction method for detection of Plum pox potyvirus (PPV) in leaves of different Prunus sp. using developed real-time RT-PCR assay. Advantages and disadvantages of compared methods are described in the view of sensitivity, reproducibility and in terms of laboratory use. The results suggest that the column based totRNA extraction method is more effective for apricot, plum and peach. In the case of damson the differences in realtime PCR results between both extraction methods were negligible. In case of negative results obtained with automated method, manual column based extraction method should be used additionally.
\end{abstract}

Key words: $18 \mathrm{~S}$ rRNA, MGB, PCR inhibition, PPV
IZVLEČEK

\author{
RASTLINSKA VRSTA IN METODA IZOLACIJE \\ CELOKUPNE RNA VPLIVATA NA USPEŠNOST \\ DETEKCIJE VIRUSA ŠARKE S PCR V REALNEM \\ ČASU
}

Uspešnost izolacije RNA je osnova za uspešno izvedbo reakcije PCR v realnem času (qPCR). V svojem delu smo primerjali ročno in avtomatsko metodo izolacije celokupne RNA (totRNA) iz listov različnih rastlinskih vrst iz rodu Prunus. Uspešnost izolacije totRNA smo preverjali z uvedeno metodo qPCR za detekcijo virusa šarke (Plum pox potyvirus PPV). Prednosti in slabosti uporabljenih metod smo ugotavljali s primerjavo občutljivosti detekcije, ponovljivosti in intenzivnosti laboratorijskega dela. Rezultati raziskave so pokazali, da je ročna metoda izolacije totRNA učinkovitejša pri marelicah, breskvah in slivah, medtem ko so bile razlike med obema metodama pri ciborah zanemarljive. Pri uporabi preizkušene avtomatske metode izolacije totRNA je priporočljivo, da $\mathrm{v}$ primeru negativnih rezultatov le-te še dodatno preverimo $\mathrm{z}$ uporabo ročne metode izolacije.

Ključne besede: $18 \mathrm{~S}$ rRNA, MGB, inhibicija PCR, PPV

\section{INTRODUCTION}

Sharka caused by the Plum pox virus (PPV) is the most devastating viral disease of stone fruits, predominately peaches, nectarines, apricots, plums and prunes. In susceptible varieties it can cause high yield losses and tree decline. The fruit quality is also affected. Estimated cost associated with sharka management worldwide in the last 30 years exceeded 10000 million euros. Costs of sanitary controls, surveys and eradication programs, but not of indirect trade losses, are included in the estimation (Cambra et al., 2006).

1* Agricultural Institute of Slovenia, Hacquetova 17, SI-1000 Ljubljana, Slovenia, Ph.D., e-mail: irena.mavric@kis.si, correspondence author

2 Agricultural Institute of Slovenia, Hacquetova 17, SI-1000 Ljubljana, Slovenia, Ph.D.

3 Omega d.o.o., Dolinškova 8, SI-1000 Ljubljana, Slovenia, Ph.D. 
Sharka was first observed in Slovenia in 1987. In the following years the presence of PPV was confirmed by Double Antibody Sandwich Enzyme-linked Immunosorbent Assay (DAS-ELISA) in samples originating from orchards, individual trees and propagation material of stone fruits. Due to the high incidence of PPV infection a systematic survey of PPV was initiated in 1998 to prevent and control the spread of sharka. Since 2000 the survey has focused mainly on nurseries, mother trees and stool-beds (Viršček Marn et al., 2004).

Due to the possibility of low virus concentration in plants and its irregular distribution, a great sensitivity and accuracy is required in PPV diagnostics.

Real-time PCR and RT-PCR is extensively used for pathogen detection and quantification; it is a method of choice for gene quantification and it is more and more used also in plant virology. Its use also eliminates or reduces the use of hazardous chemicals (e.g. ethidium bromide) in the laboratories.

Real-time PCR is a method of choice in the view of sensitivity and accuracy but the choice of target tissue and RNA extraction methods can also greatly influence the detectability of viruses in plant material. Plants are known to contain a lot of possible PCR inhibitors such as polysaccharides, polyphenols, proteins and other plant secondary metabolites (Gambino et al., 2008; Demeke and Adams, 1992; Osman and Rowhani, 2006). Their content differs between different plant organs and changes during the growing period. Previous experiences show the importance of validating RNA extraction procedure for different sample matrixes and the ability of the extraction method to provide a suitable nucleic acid free of PCR inhibitors from each sample matrix. Numerous RNA extraction methods have been used in the preparation of total RNA (totRNA) from woody plants with a more or less sufficient quantity of isolated totRNA and reduction of inhibitors, but most of them are time consuming and technically demanding (Gambino et al., 2008; Singh et al., 2002; Maliyakal, 1992).

In the present work we have compared one manual and one automated method for totRNA extraction from leaves of different Prunus sp. The quality and quantity of extracted totRNA was evaluated using developed real-time RT-PCR assay for the detection of PPV. Advantages and disadvantages of compared methods are discussed in the view of sensitivity, reproducibility and in terms of laboratory activities.

\section{MATERIALS AND METHODS}

\subsection{Plant material}

10 samples of each of 4 different Prunus species ( $P$. armeniaca (apricot), $P$. domestica ssp. domestica (plum), $P$. domestica ssp. insititia (damson) and P. persica (peach)) were included in the study. Leaves were collected from PPV infected trees previously tested by DAS-ELISA. For each plant species a negative tree was also included.

\subsection{Total RNA extraction}

TotRNA was extracted from leaf tissue of different Prunus species by two extraction methods. Extracts were prepared by homogenizing $100 \mathrm{mg}$ of fresh leaf tissue in $1100 \mu \mathrm{L}$ of RLT extraction buffer (RNeasy Plant Mini kit (Qiagene, Valencia, USA)). The homogenisation was done using TissueLyser (Retsch, Haan, Germany) shaker for $3 \mathrm{~min}$ at $30 \mathrm{~Hz}$ in the presence of one stainless steel bead of $5 \mathrm{~mm}$ in diameter. Extracts were centrifuged and supernatant was used for further totRNA extraction.

In Method 1 (manual method), $450 \mu \mathrm{L}$ of each extract were used for totRNA extraction using RNeasy Plant Mini kit (Qiagene, Valencia, USA) according to the manufacturer's instructions. The totRNA elution volume was $50 \mu \mathrm{L}$.

In Method 2 (automatic method), the other $450 \mu \mathrm{L}$ of each extract were used for totRNA extraction using RNeasy Tissue Kit (Qiagene, Valencia, USA) with KingFisher $\mathrm{mL}$ instrument (Thermo Electron, Vantaa, Finland), and according to the manufacturer's instructions. The totRNA elution volume was $100 \mu \mathrm{L}$.

$5 \mu \mathrm{L}$ of isolated totRNA were treated with DNase I for further analysis with real-time PCR method. The reaction conditions were according to the manufacturer's instructions (Invitrogen Corporation, Carlsbad, USA), using $1 \mathrm{U}$ of DNase I. The final volume of the reaction was $50 \mu \mathrm{L}$. Aliquots of the resulting RNA were analyzed by electrophoresis on $1 \%$ agarose gel with ethidium bromide staining to check its quantity and integrity (data not shown).

\subsection{Reverse transcription}

Equalized amounts of DNase treated totRNA (according to agarose gel analysis) was reverse transcribed using a cDNA Archive kit (Applied Biosystems, Foster City, USA) according to manufacturer's instructions with minor modifications. $25 \mathrm{U}$ of RNase inhibitor (Applied Biosystems, Foster City, USA) were added to the final volume of $25 \mu \mathrm{L}$. Reactions were incubated at $25^{\circ} \mathrm{C}$ for $10 \mathrm{~min}$ followed by $37^{\circ} \mathrm{C}$ for two hours.

\subsection{Real-time PCR primers and probe design}

A high homology 103 bp region of the PPV genome was selected as a target for PCR amplification by aligning 61 sequences published in GenBank database. Primer Express software v2.0 (Applied Biosystems, Foster City, USA) was used to design primers and sequence specific hydrolyzing TaqMan MGB probe (Table 1). The probe was labeled at the 5'-end with 6-carboxyfluorescein (FAM) dye. A GenBank 
Total RNA extraction method and Prunus species influence the detection of Plum pox potyvirus by real-time RT-PCR

BLAST search for short nearly exact matches revealed no with other than the region of interest in the PPV genome. significant database alignments of either primer or the probe

Table 1: Primers and probe used for PPV detection

\begin{tabular}{lll}
\hline Primer name & Orientation & Sequence $\left(5^{\prime} \rightarrow 3^{\prime}\right)$ \\
\hline PPV-f & forward & GGA GAC ACA AGT GGA GTA TCC AAT AAA \\
PPV-r & reverse & AAT GTA CGC TTC AGC CAC GTT A \\
PPV-probe & probe & FAM-CAC TTT TAG ACA AAT TAT GGC A-MGB \\
\hline
\end{tabular}

Assay specific for eukaryotic 18S rRNA (PDARS, Applied Biosystems, Foster City, USA) and TaqMan RNaseP Detection Reagents (Applied Biosystems, Foster City, USA) were used for confirmation of successful totRNA extraction and for detection of inhibitors in real-time PCR.

\subsection{Real-time PCR (TaqMan) assay}

The cDNA of each sample was used in separate real-time PCR reactions for detection of PPV and $18 \mathrm{~S}$ rRNA.

The $20 \mu \mathrm{L}$ real-time PCR reactions for PPV were performed in $1 \mathrm{X}$ TaqMan Universal Master Mix (Applied Biosystems, Foster City, USA), with $900 \mathrm{nM}$ of each primer and $200 \mathrm{nM}$ probe (Table 1) and 1/10 diluted cDNA as a template.

The $20 \mu \mathrm{L}$ real-time PCR reactions for 18S rRNA were carried out according to the manufacturer's instructions with $1 / 10$ diluted cDNA as a template.

Real-time PCR reactions were run in duplicates for each undiluted or diluted cDNA on ABI PRISM 7500 (Applied Biosystems, Foster City, USA) using universal cycling conditions $\left(50^{\circ} \mathrm{C}\right.$ for $2 \mathrm{~min}, 95^{\circ} \mathrm{C}$ for $10 \mathrm{~min}, 45$ cycles of $95^{\circ} \mathrm{C}$ for $15 \mathrm{~s}$ and $60^{\circ} \mathrm{C}$ for $1 \mathrm{~min}$ ). Data were acquired and analyzed using the ABI PRISM 7500 Real-Time PCR System Sequence Detection System Software v1.3.

cDNA from a non-infected plant of each Prunus species was used as a negative control. A PCR non-template control (NTC) was set up with molecular grade water instead of template. 10-fold serial dilutions of cDNA of each Prunus species (samples: apricot 2, damson 10, peach 2, plum 3) were used to obtain standard calibration curve for PPV. For the assessment of inter-run variability a standard calibration curve of three 10fold serial dilutions of the same sample (apricot 2) was prepared on each of four different real-time PCR plates.

The 18S rRNA assay was used for confirmation of successful totRNA extraction. Additionally, assay for RNase P gene was used for detection of inhibitors in real-time PCR step. 10 $\mathrm{ng} / \mu \mathrm{L}$ of control human DNA from TaqMan RNaseP Detection Reagents (Applied Biosystems, Foster City, USA) was added to each real-time PCR reaction as external standard of inhibition control.

\subsection{Performance of real-time PCR}

The ABI Prism 7500 Real-Time PCR System Sequence Detection Software v1.3 generated fluorescence data. For the comparability of the results, identical settings for threshold and baseline were used in all experiments for PPV detection. The baseline was established automatically and the threshold was set at 0.2 . The dynamic range of PPV real-time PCR reactions was determined by performing 10-fold serial dilutions of each Prunus species template cDNA in water. Standard calibration curves were obtained by plotting cycle threshold $(\mathrm{Ct})$ values against the log of the sample cDNA dilutions.

The real-time PCR efficiency was calculated by the following equation: PCR efficiency $[\mathrm{E}]=10^{(1 /-\mathrm{S})}$ (Pfaffl, 2001; Rasmussen, 2001).

\section{RESULTS}

\subsection{Total RNA extraction}

The quantity of extracted totRNA differed greatly between plant species. The quantity of totRNA from peach samples with Method 1 was high and uniform while the quantity with Method 2 was much lower and there was a big variation between samples (data not shown).

With other three Prunus species the used totRNA extraction methods were comparable but the quantity of extracted totRNA was low.

\subsection{Real-time PCR (TaqMan) assay}

All samples were tested for the presence of eukaryotic $18 \mathrm{~S}$ rRNA and the results confirmed successful totRNA extraction.

Real-time PCR parameters were determined by amplifying PPV RNA from different Prunus species (Table 2). A comparison was made between Method 1 and Method 2. The average coefficients of determination $\left(\mathrm{R}^{2}\right)$ were between 0.987 and 0.999 indicating a good correlation between the amount of template and $\mathrm{Ct}$ values. Efficiencies and dynamic range of detections of the real-time PCR were assessed (Table 
2). No significant differences were observed in efficiency between both isolation methods and between the tested species. Differences were observed in the dynamic range between both methods for plum and peach. The dynamic range with Method 2 was broader for plum but narrower for peach.

The amplification of 10-fold serial dilutions of selected samples of each species (apricot 2, damson 10, peach 2, plum 3) was performed. The $\mathrm{Ct}$ values of undiluted samples of peach, apricot and damson ranged between 31 and 39 while the $\mathrm{Ct}$ values of samples diluted 1/10 ranged between 18 and 23, what indicates a strong inhibition in undiluted samples using both methods. The strong inhibition of amplification was observed also for plum with Method 2 while the inhibition with Method 1 was weak.

The amplification of RNase $P$ gene as external standard of inhibition control (control human DNA) was performed for all tested samples. The results indicate elimination of inhibition in 1/10 diluted samples of all species. Standard deviation (SD) between the different samples was constant and similar to positive control (control human DNA diluted in ddH2O) (Method 1: the average $\mathrm{Ct}$ is $27.33 \pm 0.14$ and Method 2: the average $\mathrm{Ct}$ is $27.07 \pm 0.13)$.

Table 2: Comparison of dynamic ranges, efficiencies (E) and coefficients of determination $\left(\mathrm{R}^{2}\right)$ between both totRNA extraction methods and plant species

Method 1

Method 2

\begin{tabular}{lllllll} 
& Dynamic range & $\mathrm{E}$ & $\mathrm{R}^{2}$ & Dynamic range & $\mathrm{E}$ & $\mathrm{R}^{2}$ \\
\hline plum & $5 \times 10^{-1}-10^{-4}$ & 2.08 & 0.987 & $5 \times 10^{-1}-10^{-6}$ & 2.01 & 0.996 \\
peach & $5 \times 10^{-1}-10^{-6}$ & 1.99 & 0.995 & $5 \times 10^{-1}-10^{-4}$ & 2.06 & 0.994 \\
apricot & $5 \times 10^{-1}-10^{-6}$ & 2.04 & 0.999 & $5 \times 10^{-1}-10^{-6}$ & 1.95 & 0.995 \\
damson & $5 \times 10^{-1}-10^{-6}$ & 1.97 & 0.999 & $5 \times 10^{-1}-10^{-6}$ & 2.02 & 0.997 \\
\hline
\end{tabular}

Most of tested samples were in linear dynamic range of specific species independently of the amount of totRNA used for reverse transcription reactions. All other samples were treated as negative (Fig. 1). Only four apricot samples were found negative with Method 2 and one of them also with Method 1.

According to average $\mathrm{Ct}$ of tested samples, the totRNA extraction from plum with Method 1 was much more effective than the extraction with Method 2. The average difference in $\mathrm{Ct}$ between Method 1 and Method 2 for all 10 samples was $6.65 \pm 3.79$. The Method 1 performed better.
For damson we observed lower variability in average $\mathrm{Ct}$ compared to plum. The average difference in $\mathrm{Ct}$ between Method 1 and Method 2 for all damson samples was $-0.34 \pm 0.85$. Both methods were comparable.

The average difference in $\mathrm{Ct}$ between Method 1 and Method 2 for all 10 samples of peach was $2.22 \pm 1.48$. The Method 1 performed better.

The average difference in $\mathrm{Ct}$ between Method 1 and Method 2 for positive apricot samples was $4.04 \pm 2.20$. The Method 1 performed better. 
Total RNA extraction method and Prunus species influence the detection of Plum pox potyvirus by real-time RT-PCR

Figure 1: Real-time PCR cycle threshold (Ct) values for detection of PPV in samples of four different Prunus species extracted with two different totRNA extraction methods.

Prunus domestica ssp. insititia (DAMSON)
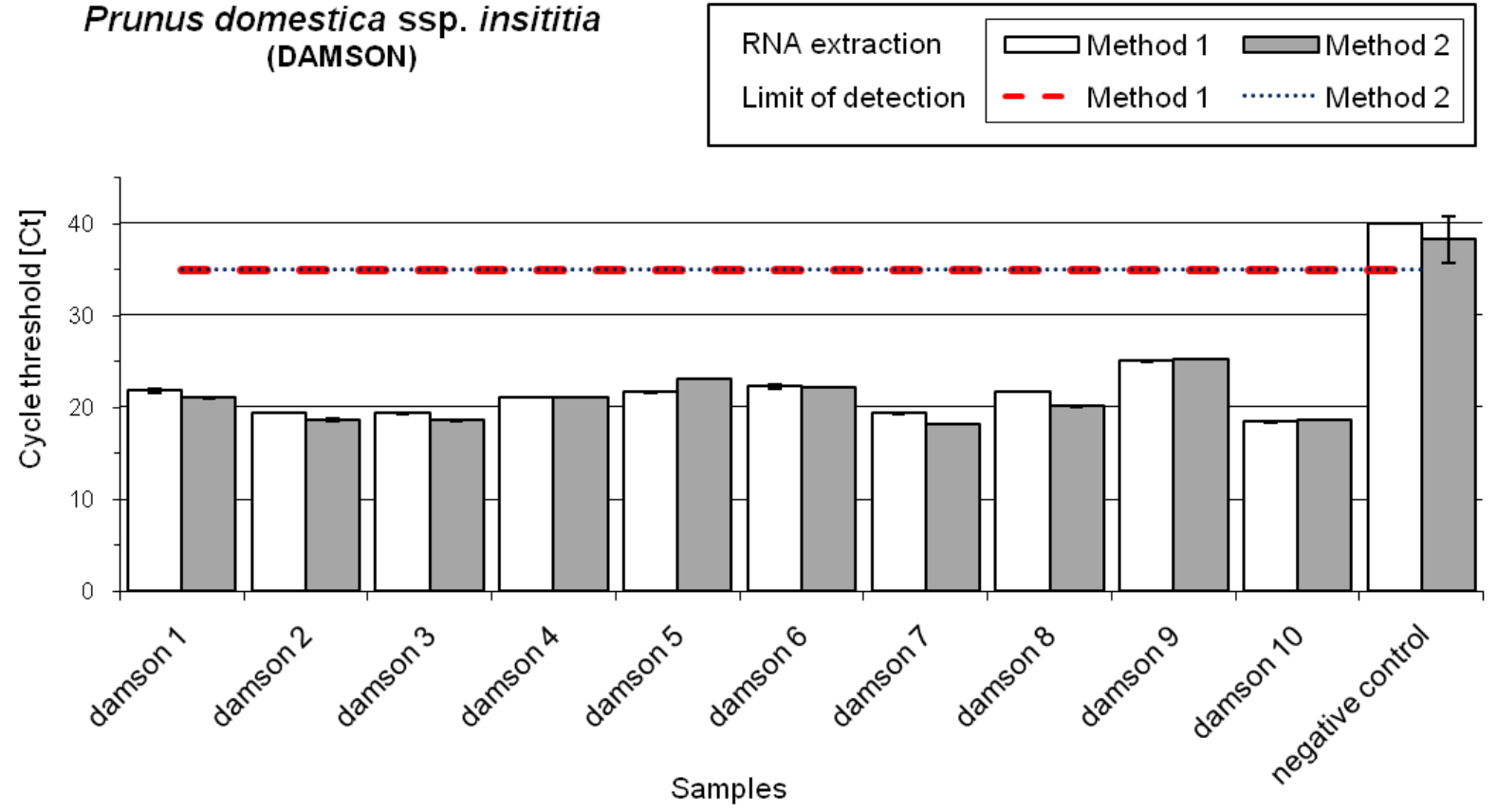

Prunus armeniaca (APRICOT)

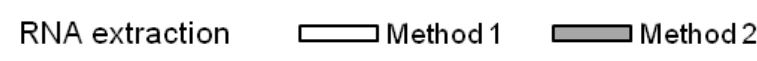

Limit of detection $\quad$ - - - Method $1 \quad$........... Method 2

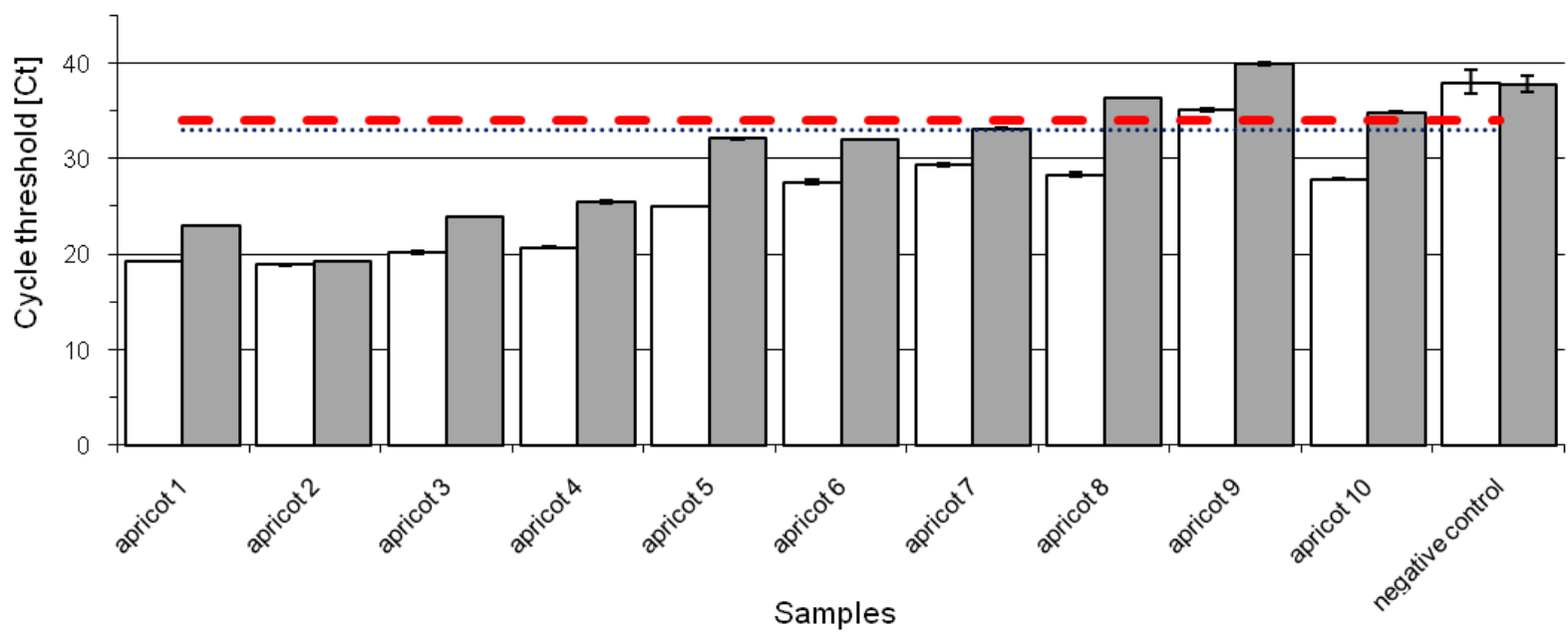



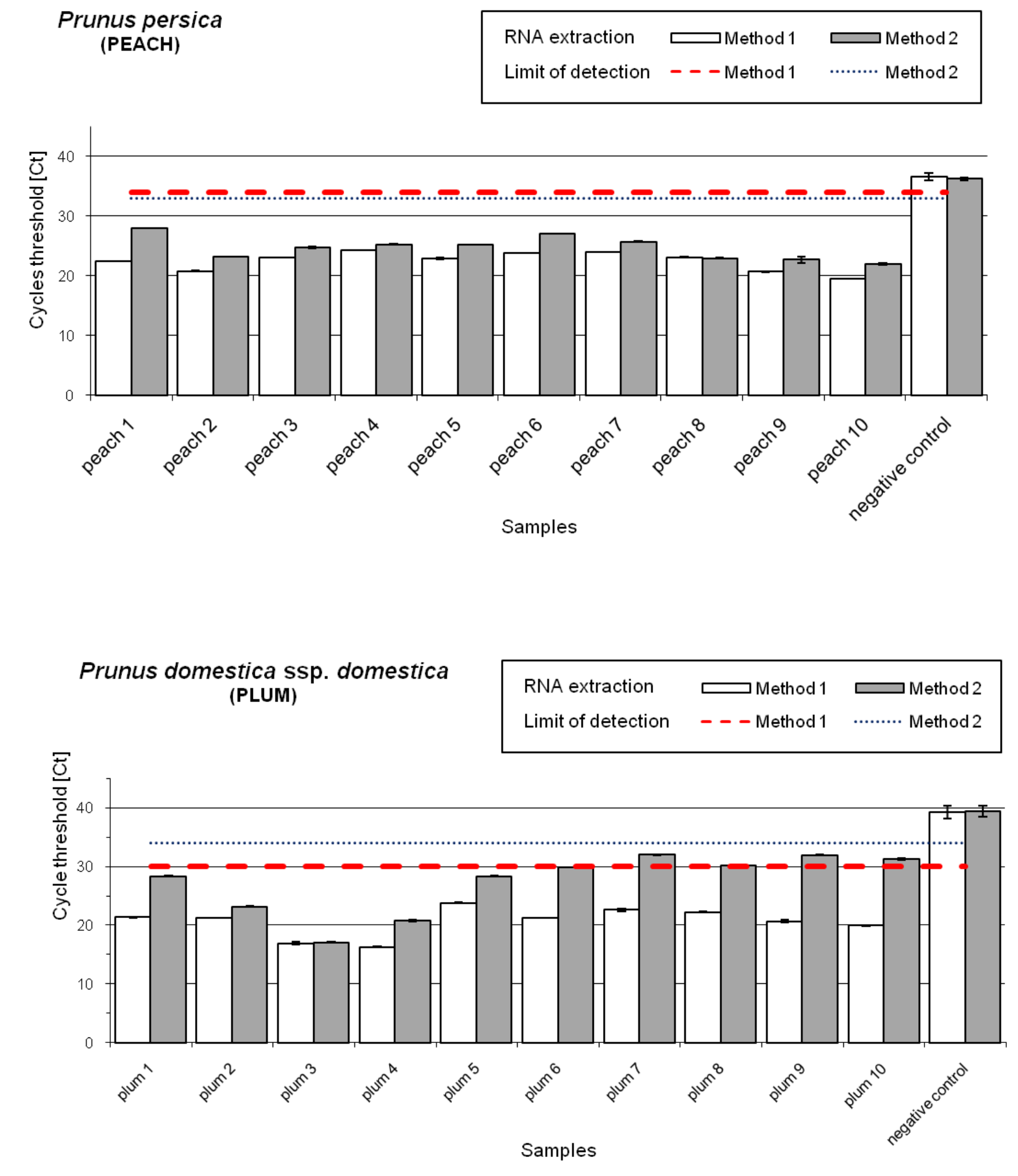

Samples with $\mathrm{C}_{\mathrm{t}}$ values of less than marked $\mathrm{Ct}$, indicating the detection limit for each totRNA extraction method and tested Prunus species, were considered as positive. 


\subsection{Inter-run variability}

Inter-run variability was assessed by preparing the standard curves with three 10 -fold serial dilutions of the same sample in four different plates. The quantification was linear over a range of all three log units. The average slope of all compared standard curves was -
$3.355 \pm 0.028$, the efficiency was $1.986 \pm 0.011$ and the average $\mathrm{R}^{2}$ was $0.997 \pm 0.003$ (data not shown). These results show that the conditions of amplification on all plates were stable and the comparison of the results from different plates was possible.

\section{DISCUSSION}

PCR based methods, including real-time PCR are widely used for the detection of plant viruses. The choice of nucleic acid extraction procedure can greatly influence the reliability of detection and quantification of target sample. It is important to validate the extraction procedure for different sample matrixes and the ability of the extraction method to provide suitable nucleic acid from each matrix. It is known that different matrixes can contain different substances that could affect the efficiency and reliability of real-time PCR (Cankar et al., 2006). Components that inhibit the amplification of nucleic acids by PCR based methods are present with the target nucleic acids from many sources and inhibitory effects may have important implications for clinical investigations, investigations in food and environmental screening (Wilson, 1997). The mechanism of inhibition is considered to be chelation of the $\mathrm{Mg}^{2+}$ cofactor which is important for Taq polymerase activity, or by binding to target DNA/RNA/Taq polymerase or by inhibition of Taq polymerase (Wilson, 1997; Mayr et al., 2005). Inhibitors can generate inaccurate quantitative results and high degree of inhibition can create false-negative results (Nolan et al., 2006).

The significant reduction in the sensitivity and kinetics of real-time PCR caused by inhibitory components frequently found in biological samples is well known (Rådström et al., 2004; Jiang et al., 2005).

Different Prunus species may have different concentration of secondary metabolites, similar to other plants like citrus, strawberry and blackberry (Borah et al., 2008; Wei et al., 2008) which can have inhibitory effects. In plant tissue we usually find polysaccharides and polyphenols as components with inhibitory effect on PCR (Demeke and Adams, 1992). Numerous extraction methods have been used in the preparation of totRNA from plant samples with a more or less sufficient quantity of isolated totRNA and reduction of inhibitors (Gambino et al., 2008; Singh et al., 2002; Maliyakal, 1992; Koonjul et al., 1999; Thompson et al., 2003). These approaches are often time-consuming but they are essential for reliable diagnostic work.

In our study one manual and one automated totRNA extraction method were compared in terms of elimination of potential PCR inhibitors. The column based method for totRNA extraction (e.g. RNeasy Plant Mini Kit) is easily adapted for high throughput processing, and can yield amounts of up to $10 \mu \mathrm{g}$ of totRNA from small amount of starting material, which is sufficient for real-time PCR applications. Samples isolated by the column based method contain fewer impurities such as phenol compounds which are a particular problem with plant samples and have a significant influence on the efficiency of PCR amplification (Singh and Singh, 1996; Singh, 1998; Myslik and Nassuth, 2001). The use of RNeasy columns manually is time consuming but a higher quantity of totRNA is isolated. An automated alternative for manual extraction with RNeasy columns could be advanced technology, instrument called QIAcube (Qiagen) which we were not able to use during our experiments. Sample preparation on the QIAcube use RNeasy spin columns follows the same steps as the manual procedure and no change in purification chemistry is required.

The KingFisher instrument uses patented technology in which magnetic rod moves particles through purification process. The technology used is based on silica particles which bind totRNA in the presence of chaotropic salt. The use of KingFisher instrument is automated and fast, it saves time and money. The financial disadvantage is the initial investment into the instrument but it can be used for many different applications (for DNA, RNA and protein extraction) (Lassailly et al., 2007; Zhao et al., 2008; Josefsen et al., 2007).

For comparison of manual and automated totRNA extraction we developed a real-time PCR assay that can be used for detection of PPV in different Prunus species.

With both totRNA extraction methods real-time PCR assay for PPV detection was shown to be reproducible and linear amplification was achieved over a range of 4 or 5 orders of magnitude. The range depends on the extraction method and the Prunus species used.

The results of this study suggest that the column based totRNA extraction method is more effective for apricot, plum and peach. It is a manual method and more time is 
needed for processing of the same amount of samples compared to automated method using KingFisher instrument. The differences between both methods were very small when analyzing damson. For the processing high number of samples in large scale detection of PPV the automated method such as KingFisher instrument is more appropriate. It saves time even if the amount of extracted totRNA is not as high as with manual method. According to our results we would recommend to use cDNA diluted $1 / 10$ in real-time PCR of Prunus sp. In case of negative results obtained with automated method, manual column based extraction method should be used additionally.

\section{ACKNOWLEGEMENTS}

The work was financed by the Agency for Research of the Republic of Slovenia (Grant no. P4-0072).

\section{REFERENCES}

Borah, B.K., Anthony Johnson, A.M., Sai Gopal, D.V.R. and Dasgupta I. 2008. A comparison of four DNA extraction methods for the detection of Citrus yellow mosaic badna virus from two species of citrus using PCR and dot-blot hybridization. J. Virol. Methods 151, 321-324.

Cambra, M., Capote, N., Myrta, A. and Llácer, G. 2006. Plum pox virus and estimated costs associated with sharka disease. EPPO Bull. 36, 202-204.

Cankar, K., Štebih, D., Dreo, T., Žel, J. and Gruden, K. 2006. Critical points of DNA quantification by real-time PCR - Effects of DNA extraction method and sample matrix on quantification of genetically modified organisms. BMC Biotechnol. 6, 37-51.

Demeke, T. and Adams, R.P. 1992. The effects of plant polysaccharides and buffer additives on PCR. BioTechniques 12, 332-334.

Gambino, G., Perrone, I. and Gribaudo, I. 2008. A rapid and effective method for RNA extraction from different tissues of grapevine and other woody plants. Phytochem. Anal. 19, 520-525.

Jiang, J., Alderisio, A.K., Singh, A. and Xiao, L. 2005. Development of Procedures for Direct Extraction of Cryptosporidium DNA from Water Concentrates and for Relief of PCR Inhibitors. Appl. Environ. Microbiol. $71,1135-1141$.

Josefsen, M.H., Krause, M., Hansen, F. and Hoorfar, J. 2007. Optimization of a 12-Hour TaqMan PCR-Based Method for Detection of Salmonella Bacteria in Meat. Appl. Environ. Microbiol. 73, 3040-3048.

Koonjul, P.K., Brandt, W.B., Farrant, J.M. and Lindsey, G.G. 1999. Inclusion of polyvinyl pyrrolidone in the polymerase chain reverses the inhibitory effects of polyphenolic contamination of RNA, Nucleic Acids Res. 27, 915-916.

Lassailly, F., Mozziconacci, M.-J., Noguchi, T., Bechlian, D., Adelaide, J., Fina, F., Martin, P.-M., Sobol, H., Xerri, L., Birnbaum, D. and Chabannon, C. 2007. Comparison of a Selection of Rapid Automated DNA and RNA Extraction Technologies for Detection of
Somatic or Constitutional Gene Abnormalities in Cancer Diagnosis. Cell Preserv. Technol. 5, 2-15.

Malvick, D.K. and Grunden, E. 2005. Isolation of fungal DNA from plant tissues and removal of DNA amplification inhibitors. Mol. Ecol. Notes 5, 958-960.

Maliyakal, E.J. 1992. An efficient method for isolation of RNA and DNA from plants containing polyphenolics. Nucleic Acids Res. 20, 2381.

Mayr, W., Winidhorst, S. and Hillemeier, K. 2005. Antiproliferative plant and synthetic polyphenolics are specific inhibitors of vertebrate inositol-1,4,5trisphosphate 3-kinases and inositol polyphosphate multikinase. J. Biol. Chem. 280, 13229-13240.

Myslik, J.T. and Nassuth, A. 2001. Rapid detection of viruses, transgenes, and mRNAs in small plant leaf samples. Plant Mol. Biol. Rep. 19, 329-340.

Nolan, T., Hands, R.E., Ogunkolade, W. and, Bustin, S. 2006. SPUD: A quantitative PCR assay for the detection of inhibitors in nucleic acid preparation. Anal. Biochem. $351,308-310$

Osman, F., Rowhani, A. 2006. Application of a spotting sample preparation technique for the detection of pathogens in woody plants by RT-PCR and real-time PCR (TaqMan). J. Virol. Methods 133, 130-136.

Pfaffl, M.W. 2001. A new mathematical model for relative quantification in real-time RT-PCR. Nucleic Acids Res. 29, e45.

Rasmussen, R. 2001. Quantification on the LightCycler. In Meuer, S., Wittwer, C., Nakagawara, K. (Eds): Rapid Cycle Real-time PCR, Methods and Applications. Springer Press, Heidelberg, pp. 21-34.

Rådström, P., Knutsson, R., Wolffs, P., Lövenklev, M. and Löfström, C. 2004. Pre-PCR processing: strategies to generate PCR-compatible samples. Mol. Biotechnol. 26, 133-146.

Singh, R.P. 1998. Reverse-transcription polymerase chain reaction for the detection of viruses from plants and aphids. J. Virol. Methods 74, 125-138. 
Total RNA extraction method and Prunus species influence the detection of Plum pox potyvirus by real-time RT-PCR

Singh, M. and Singh, R.P. 1996 Factors affecting detection of PVY in dormant tubers by reverse transcription polymerase chain reaction and nucleic acid spot hybridization. J. Virol. Methods 60, 47-57.

Singh, R.P., Nie, X., Singh, M., Coffin, R. and Duplessis, P. 2002. Sodium sulphite inhibition of potato and cherry polyphenolics in nucleic acid extraction for virus detection by RT-PCR. J. Virol. Methods 99, 123-131.

Thompson, J.R., Wetzel, S., Klerks, M.M., Vaskova, D., Schoen, C.D., Spak, J. and Jelkmann, W. 2003. Multiplex RT-PCR detection of four aphid-borne strawberry viruses in Fragaria spp. in combination with a plant mRNA specific internal control. J. Virol. Methods 111, 85-93.

Viršček Marn, M., Mavrič, I., Benko-Beloglavec, A., Knapič, V. and Weilguny, H. 2004. Results of the systematic survey and control of Plum pox potyvirus in Slovenia. EPPO Bull. 34, 127-131.

Wei, T., Lu, G. and Clover, G. 2008. Novel approaches to mitigate primer interaction and eliminate inhibitors in multiplex PCR, demonstrated using an assay for detection of three strawberry viruses. J. Virol. Methods $151,132-139$

Wilson, I.G. 1997. Inhibiton and Fascilitation of Nucleic Acid Amplification. Appl. Environ. Microbiol. 63, 37413751 .

Zhao, Z., Peytavi, R., Diaz-Quijada, G.A., Picard, F.J., Huletsky, A., Leblanc, E., Frenette, J., Boivin, G., Veres, T., Dumoulin, M.M. and Bergeron, M.G. 2008. Plastic Polymers for Efficient DNA Microarray Hybridization: Application to Microbiological Diagnostics. J. Clin. Microbiol. 46, 3752-3758. 